\title{
Use of two different carriers in a packed bed reactor for endopolygalacturonase production by a yeast strain
}

\author{
Catarina Almeida ${ }^{\mathrm{a}, \mathrm{b}}$, Tomáš Brányik ${ }^{\mathrm{a}}$, Pedro Moradas-Ferreira ${ }^{\mathrm{c}, \mathrm{d}}$, José Teixeira ${ }^{\mathrm{a}, *}$ \\ ${ }^{a}$ Centro de Engenharia Biológica, Universidade do Minho, Campus de Gualtar, 4710-057 Braga, Portugal \\ ${ }^{\mathrm{b}}$ Instituto Superior de Ciências da Saúde-Sul, Quinta da Granja, 2829-511 Monte DA Caparica, Portugal \\ ${ }^{\mathrm{c}}$ Instituto de Biologia Molecular e Celular, Rua do Campo Alegre 823, 4150-180 Porto, Portugal \\ ${ }^{\mathrm{d}}$ Instituto de Ciências Biomédicas Abel Salazar, Universidade do Porto, Largo Prof. Abel Salazar 2, P-4099-003 Porto, Portugal
}

Received 16 December 2003; accepted 20 July 2004

\begin{abstract}
A packed bed reactor (PBR) design was tested for the purpose of continuous pectinase production with yeasts, as a possible alternative to the traditional batch process using fungal cultures. Two different carriers - a porous glass (Siran) and a cellulosic carrier obtained from spent grains (barley) - were used to immobilize Kluyveromyces marxianus CCT 3172, a yeast strain secreting endopolygalacturonase. To improve cell distribution throughout the column, part of the outflow was recycled. Cell loads of 0.204 and $0.247 \mathrm{~g}$ biomass $/ \mathrm{g}_{\text {carrier }}$ were obtained at the top and bottom of the PBR with spent grains, respectively. Using the PBR with Siran as the immobilization support, $0.071 \mathrm{~g}_{\text {biomass }} / \mathrm{g}_{\text {carrier }}$ was the biomass load at the top of the column while at the bottom a value of $0.147 \mathrm{~g}_{\text {biomass }} / \mathrm{g}_{\text {carrier }}$ was found. The highest value for pectinase volumetric productivity $\left(P_{\mathrm{V}}=1.68 \mathrm{U} / \mathrm{ml} \mathrm{h}\right)$ was achieved in the PBR with Siran for a $D=0.260 \mathrm{~h}^{-1}$ and a glucose concentration on the inlet of $S_{\text {in }}=40 \mathrm{~g} / \mathrm{l}$. Both carriers were suitable for pectinase production. The best results were obtained with a high and uniform biomass concentration in the column, together with high dilution rates and total glucose consumption.
\end{abstract}

(C) 2004 Elsevier Ltd. All rights reserved.

Keywords: Continuous reactor; Immobilized yeast cells; Kluyveromyces marxianus; Pectinase; Siran; Spent grains

\section{Introduction}

Pectinases are a group of enzymes acting on pectin and other pectic substances found in vegetable tissues. Pectin consists of a $\alpha-1,4$ polymer of D-galacturonic acid; the main chain is $60-90 \%$ methylated and includes rhamnose units and side chains of arabinan, galactan and arabinogalactan. This complex polymer has a structural, scaffolding function in the primary cell wall and in the middle lamella of plant tissues [1]. In natural habitats, several microorganisms secrete different pectolytic enzymes to invade the cell walls and thus grow on the rich substrates found in plants. In the industrial world, pectinases have found use in any process that deals with extracting juices from fruits and vegetables and in the processing of plant

\footnotetext{
* Corresponding author.

E-mail address: jateixeira@deb.uminho.pt (J. Teixeira).
}

tissues. Some examples are: in fruit juice clarification and viscosity reduction, in preliminary grape treatment in wine industries, in tomato pulp extraction, in chocolate and tea fermentation, vegetable waste treatment, fibre degguming in textile and paper industries [2]. Aspergillus niger is currently the only microorganism used for pectinase industrial production. It secretes a mixture of pectolytic enzymes (polygalacturonases, polymethylgalacturonases, pectin lyases and pectin esterases) together with other degrading enzymes such as arabinofuranosidases and amyloglucosidases [3]. In fact, commercial pectinase is a blend of enzymes. This can be useful due to the complexity of plant tissues and all the different chemical bonds to hydrolyse, but in some industrial cases a specific type of pectinase or a specific blend is needed [4]. The yeast strain Kluyveromyces marxianus CCT 3172 was selected from a cocoa fermentation as a good endopolygalacturonase producer $[5,6]$. 
Continuous production of an endopolygalacturonase from yeast would be an interesting alternative to the current fungal batch production. To increase the productivity of continuous processes, high cell density systems can be used. Some carriers have been successfully tested for yeasts and bacteria immobilization, namely porous materials such as porous glass and ceramic, synthetic polymers, cellulosic fibres and cellulose derivatives, activated charcoal, artificial polymers and gel matrixes as k-carrageenan, $\mathrm{Ca}$ and $\mathrm{Ba}$ alginate, and pectate [7-13].

In this work, a packed bed reactor (PBR) was chosen for pectinase production. Two carriers were tested for cell immobilization: a commercial porous silicate glass (Siran) and a recently tested cellulosic support, prepared from spent grains, a by-product of the brewing industry. Although Siran has been used with satisfying results for cell and enzyme immobilization [14-18], its high cost can be a drawback for industrial productions. The cellulosic carrier has already been tested with a brewing strain (Saccharomyces uvarum) and was found to be very efficient, having a high yeast loading capacity, together with an easy preparation, reusability, availability and an inert, non-toxic nature $[19,20]$.

\section{Materials and methods}

\subsection{Media and strain}

Wild-type K. marxianus CCT 3172 used to inoculate both continuous reactors was pre-grown in $200 \mathrm{ml}$ (in $500 \mathrm{ml}$ Erlenmeyer flasks) semi-synthetic media at $30{ }^{\circ} \mathrm{C}, 120 \mathrm{rpm}$ for $24 \mathrm{~h}$.

The semi-synthetic media (SS) for yeast growth included (g/l): $5 \mathrm{~K}_{2} \mathrm{HPO}_{4}, 2\left(\mathrm{NH}_{4}\right)_{2} \mathrm{SO}_{4}, 0.4 \mathrm{MgSO}_{4} \cdot 7 \mathrm{H}_{2} \mathrm{O}, 1$ yeast extract, and different glucose concentrations $(20,40$, $80)$.

\subsection{Carriers}

The carriers used were porous silicate glass beads (Siran, QVF Engineering, Mainz, Germany, with bead diameters 2$3 \mathrm{~mm}$ and porosity 50-65\%) and a cellulosic support prepared from spent grains, a by-product of the brewing industry. Siran beads were washed in distilled water and autoclaved twice before the first use. The steps followed to obtain the carrier from spent grains are described in Brányik et al. [19]. Hundred grams of dry spent grains was submitted to an acid treatment $(1500 \mathrm{ml}$ of a $3 \%(\mathrm{v} / \mathrm{v}) \mathrm{HCl}$ solution, $60{ }^{\circ} \mathrm{C}, 2.5 \mathrm{~h}$ ) in order to hydrolyse the starchy endosperm and embryo of the barley kernel. After cooling, it was washed with water and dried. The remaining solids (ca. $30 \mathrm{~g}$ ) were partially delignified with $\mathrm{NaOH}(500 \mathrm{ml}$ of a $2 \%(\mathrm{w} / \mathrm{v})$ solution, $30{ }^{\circ} \mathrm{C}, 24 \mathrm{~h}, 120 \mathrm{rpm}$ ). Several washing steps with water were needed to reach a neutral $\mathrm{pH}$. After drying, the carrier (ca. $10 \mathrm{~g}$ ) was ready to be used.

\subsection{Enzyme assays}

Endopolygalacturonase activity in the reactor effluent was assessed using the method described by Honda et al. [21]. One unit (U) is defined as $1 \mu \mathrm{mol}$ of galacturonic acid released after $1 \mathrm{~min}$ of hydrolysis of polygalacturonic acid in the presence of the enzyme at $40^{\circ} \mathrm{C}, \mathrm{pH} 4.1$.

\subsection{Analytical methods}

Glucose concentration was determined by the DNS method for reducing sugars quantification [22]. For pectinase activity determination, the samples from reactors were centrifuged, filtered and then dialyzed with a 14,000 MWCO membrane (Medicell International, London, UK) against cold distilled water for $16 \mathrm{~h}$. Lactose was used as a tracer for hydrodynamic studies. Its concentration was determined using the specific enzymatic kit for detection of lactose and D-galactose from Boehringer Manheim/Roche.

\subsection{Cells contact angle measurements}

A solution of $20 \mathrm{~g} / \mathrm{l}$ of agar and $10 \%(\mathrm{v} / \mathrm{v})$ glycerol was cast on a microscope slide. Cell samples were taken from a continuous reactor outflow and washed with a solution with increasing ethanol concentration $(10,20$ and $50 \%(\mathrm{w} / \mathrm{v}))$. One millilitres of a cell suspension in $50 \%$ ethanol with an Abs $600 \mathrm{~nm}=2.0$ was spread on the solidified agar and glycerol and allowed to dry. This step was repeated four times [23]. Contact angles were measured at room temperature using water, formamide and $\alpha$-bromonaphthalene in a contact angle apparatus (Kruss GmgH, Germany) by the sessile drop technique. The total surface tension $\left(\gamma^{\text {tot }}\right)$ and its components $\left(\gamma^{\mathrm{LW}}, \gamma^{+}, \gamma^{-}, \gamma^{\mathrm{AB}}\right)$, the values of the free energy of interaction between cells and water $\Delta G_{\mathrm{sws}}^{\text {tot }}$ and the components $\left(\Delta G_{\mathrm{sws}}^{\mathrm{LW}}, \Delta G_{\mathrm{sws}}^{\mathrm{AB}}\right)$ were calculated according to van Oss et al. [24].

\subsection{Scanning electron microscopy (SEM)}

A sample of biocatalyst was taken from the CSTR reactor, washed with water and with a solution with increasing ethanol concentration $(10,25,50,75,90,100 \%)$. It was allowed to dry for 5 days in an exicator and covered with a thin gold layer to allow for SEM observation.

\subsection{Biomass quantification}

The free biomass concentration at the reactor's outlet was measured by reading the absorbance of samples at $600 \mathrm{~nm}$ and then converting this value to dry weight per volume using an appropriate calibration curve.

At the end of the reactor operation, samples of the biocatalyst were withdrawn from different heights of the fixed bed. For the spent grains, the carrier with adsorbed yeast cells was gently washed with $200 \mathrm{ml}$ of distilled water. The 
resulting suspension was filtered and washed with water; the filter paper with carrier and immobilized cells was dried at $105^{\circ} \mathrm{C}$ for $16 \mathrm{~h}$. A washing step (during $24 \mathrm{~h}$ at $120 \mathrm{rpm}$ ) with a $3 \%(\mathrm{w} / \mathrm{v}) \mathrm{NaOH}$ solution released the attached biomass. After washing with distilled water and filtering, the biomass free carrier was dried at $105^{\circ} \mathrm{C}$ for $5 \mathrm{~h}$. The biomass weight was calculated as being the weight difference of the dry carrier before and after the $\mathrm{NaOH}$ washing [20]. Corrections of the biomass weight for the losses of carrier itself were carried out by blank experiments with clean carrier.

For the Siran carrier, the biocatalyst samples were dried for $48 \mathrm{~h}$ at $105{ }^{\circ} \mathrm{C}$ and weighed. The biomass was then combusted at $550{ }^{\circ} \mathrm{C}$ for $2 \mathrm{~h}$ and the residual material was weighted. The biomass load $\left(X_{i}\right)$ was calculated as the weight difference between the dry biocatalyst and the clean carrier. Biomass loads were expressed in $\mathrm{g}_{\text {biomass }} / \mathrm{g}_{\text {carrier }}$.

\subsection{Bioreactor start-up and operation}

Before operation, the reactor was sterilized with a hypochlorite solution (3 days). After this period of time, 10 reactor volumes of sterile distilled water were used to wash the column. The packed bed reactor (PBR) was a "Perspex" column, with height to internal diameter ratio $\left(H / D_{\mathrm{i}}\right)$ of 12 and an operation volume of $310 \mathrm{ml}$.

When using the spent grains as cells support, $25 \mathrm{~g}$ of sterile dry carrier was aseptically inserted in the column and then inoculated with a pre-grown yeast culture. After $24 \mathrm{~h}$ of batch growth in the reactor, continuous operation started by feeding SS medium with $40 \mathrm{~g} / \mathrm{l}$ glucose at the bottom of the column. A recycle rate of $40 \mathrm{ml} / \mathrm{h}$ was used during the entire operation time, by re-introducing a part of the outflow to the bottom of the column.
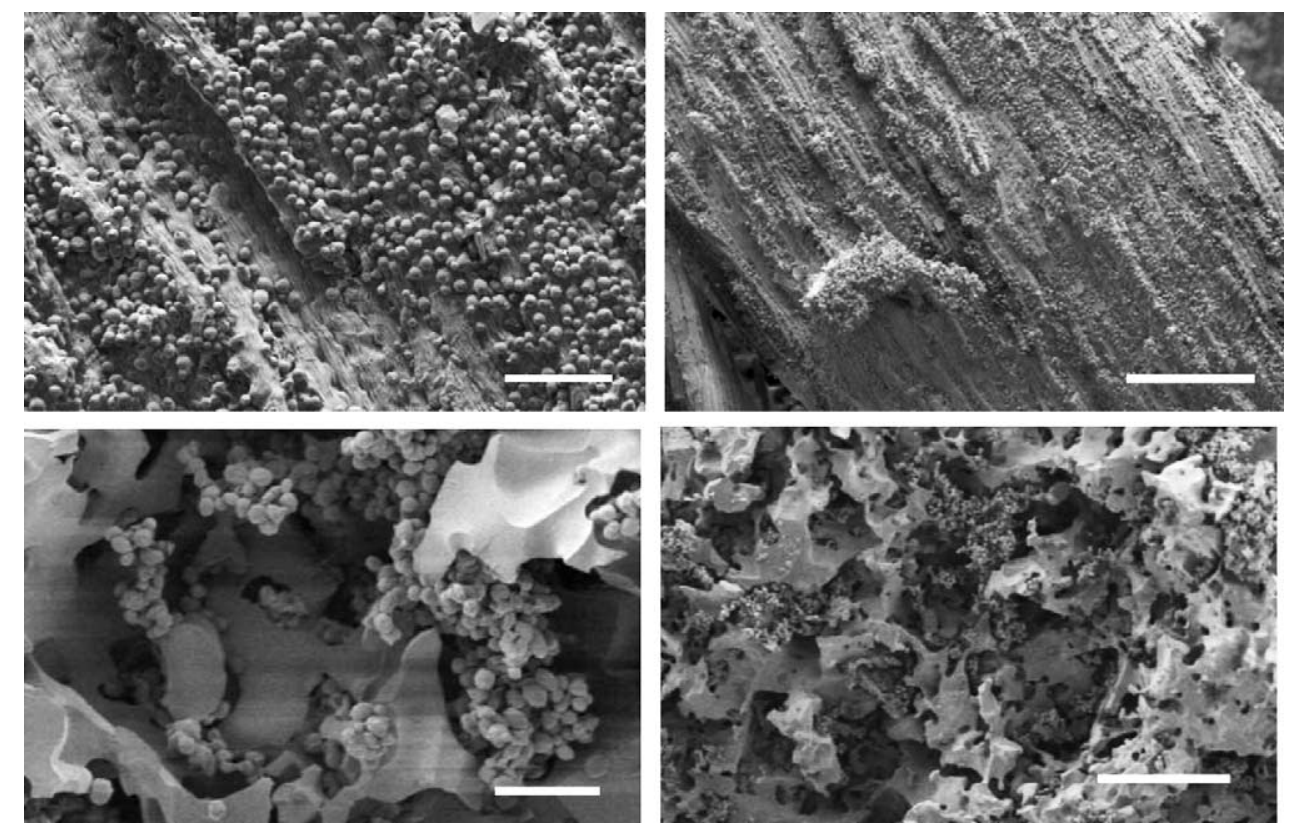

Fig. 1. SEM photos. Top images - cells on spent grains. Bottom images - cells on Siran beads. Left images - bar corresponds to $20 \mu \mathrm{m}$; Right images - bar corresponds to $100 \mu \mathrm{m}$.

When Siran was used as carrier, approximately $150 \mathrm{~g}$ of sterilized dried beads was introduced into an Erlenmeyer flask with SS medium (20 g/l glucose) and then inoculated with a pre-grown $100 \mathrm{ml}$ culture. After $24 \mathrm{~h}$ of incubation at $30{ }^{\circ} \mathrm{C}, 120 \mathrm{rpm}$, the Siran beads were transferred into the reactor which was then filled with fresh SS media (40 g/l). Continuous operation started $24 \mathrm{~h}$ after the transfer. In this experiment, the recycle rate was $200 \mathrm{ml} / \mathrm{h}$. For all the operating conditions, a minimum of five residence times was allowed before changing to another set of conditions.

The dilution rate was considered to be $D\left(\mathrm{~h}^{-1}\right)=$ volumetric feed rate/total working volume of the reactor. All assays were performed at $25^{\circ} \mathrm{C}$.

\section{Results and discussion}

\subsection{Cell immobilization}

The cellulosic carrier from spent grains is both irregular in shape and non-homogeneous in chemical composition, originating "active sites" preferably colonized by yeasts [19]. Siran beads are composed of silicate glass with an open pore structure, relatively uniform in size but with an irregular orientation and shape (Fig. 1).

Contact angles measured by the sessile drop technique [23] were used to calculate the yeast surface properties according to van Oss et al. [24,25]. The values of total surface tension and free energy of interaction for $K$. marxianus CCT 3172 cells, for base-treated spent grains carrier (T. Brányik, unpublished results) and for Siran [26] are presented in Table 1 . The high positive $\Delta G_{\mathrm{sws}}^{\mathrm{tot}}$ value found for the Siran carrier is associated with its surface 
Table 1

Surface tension $\gamma^{\text {tot }}$ and free energy of interaction for cells $K$. marxianus CCT 3172 grown in continuous culture $\left(\Delta G_{\mathrm{cwc}}^{\mathrm{tot}}\right)$, for the base-treated spent grains carrier and for $\operatorname{Siran}\left(\Delta G_{\mathrm{cwc}}^{\mathrm{tot}}\right)$

\begin{tabular}{llcl}
\hline & $\gamma^{\text {tot }}$ & $\Delta G_{\text {sws }}^{\text {tot }}$ & $\Delta G_{\text {cwc }}^{\text {tot }}$ \\
\hline Cells from continuous culture & 61.0 & - & 22.9 \\
Base-treated carrier & 41.5 & -57.7 & - \\
Siran [26] & 56.1 & 119.8 & - \\
\hline
\end{tabular}

All values in $\mathrm{mJ} / \mathrm{m}^{2}$.

hydrophilic character, and the negative value determined for the cellulosic carrier shows the presence of highly hydrophobic areas. From these values, the free energy of interaction between $K$. marxianus cells and the two different carriers was calculated [24]. The values of $\Delta G_{\mathrm{cws}}^{\mathrm{tot}}=1.86 \pm$ $8.70 \mathrm{~mJ} / \mathrm{m}^{2}$ (the wide error bar is associated with the nonuniform surface composition of the cellulosic carrier) for the interaction cells-water-spent grains and $\Delta G_{\mathrm{cws}}^{\mathrm{tot}}=55.5 \pm$ $5.0 \mathrm{~mJ} / \mathrm{m}^{2}$ for cells-water-Siran showed an energetically less favourable adhesion between yeast cells and the surface of Siran beads. These results are in agreement with the observed behaviour of cells in the two different biocatalyst beds (Fig. 1). The Siran carrier seems to immobilize cells only by spatial retention on its porous structure.

It has an open pore matrix with an important presence of void spaces, allowing liquid motion and cell percolation through the fixed bed. This originates a difference in the biomass load at different heights in the column (for distances from the top of $0,8,18$ and $31 \mathrm{~cm}$ biomass loads $\left(X_{i}\right)$ of $0.072,0.054,0.065$ and $0.143 \mathrm{~g}_{\text {biomass }} / \mathrm{g}_{\text {carrier }}$, respectively, were found at the end of the reactor operation). As it was not possible to withdraw biocatalyst samples during reactor operation, four separate assays were performed using a smaller column and $1 / 10$ of the Siran weight (approximately $15 \mathrm{~g}$ ). A fixed dilution rate of $D=0.33 \mathrm{~h}^{-1}$ was used and the four assays were stopped at 120,240, 408 and $672 \mathrm{~h}$ for immobilized biomass quantification. After $240 \mathrm{~h}$ of continuous operation, biomass load reached a stationary value (approximately $0.070 \mathrm{~g}_{\text {biomass }} / \mathrm{g}_{\text {carrier }}$ ) (Fig. 2). From these experiments, it can be assumed that the immobilized biomass inside the PBR was nearly constant after the first $240 \mathrm{~h}$ of reactor's operation.

When the cellulosic carrier was used, cells were attached to the irregular surface not only by retention inside fibres, threads and crevices, but also by cell-surface adhesion due to different interaction forces. Moreover, the spent grains packing worked as a "filter layer" giving rise to zones of local accumulation of yeasts. The $\mathrm{CO}_{2}$ bubbles formed during the experiment were to account for a sponge-like bed structure. The gas was periodically liberated through the top of the column, hence mixing the packed bed and releasing parts of the biomass deposits. At the end of the operation time, the PBR reactor had a biomass load of 0.247 g biomass $\mathrm{g}_{\text {carrier }}$ at the bottom and $0.204 \mathrm{~g}_{\text {biomass }} / \mathrm{g}_{\text {carrier }}$ at the top showing a higher homogeneity in the bed colonization than for the PBR with Siran.

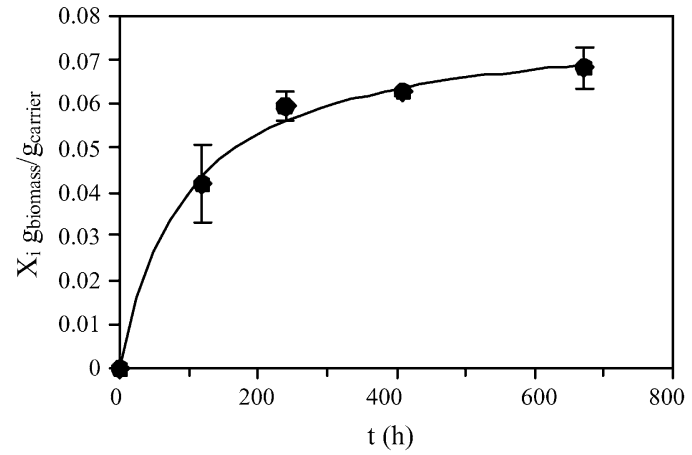

Fig. 2. Immobilized biomass load $\left(X_{i}\right)$ in the Siran packed bed (assays with the smaller column reactors).

\subsection{Hydrodynamic studies (residence time distribution)}

Experiments were carried out to study the hydrodynamic behaviour inside the PBR for both tested carriers. Lactose was used as a tracer since this particular strain of $K$. marxianus is unable to metabolize it efficiently. Besides, glucose is not totally consumed during the experiments with the tracer, which acts as a catabolic repressor to lactose consumption.

A lactose concentration step was imposed at steady-state conditions for both reactors. The residence time distribution is presented in Fig. 3a and b. When the Siran carrier was used, the best fit for experimental tracer response seems to be an ideal CSTR. For the axial dispersion model, Peclet number is the fitting parameter, defined as $u L / D$ ( $u$ being the linear velocity, $L$ the height of the biocatalyst bed and $D$ the axial dispersion coefficient); $P e=\infty$ corresponds to ideal plug flow, and $P e=0$ to ideal mixed flow. The low Peclet $(u L / D)$ value and the poor correlation obtained $\left(P e=1.07 \pm 1.01, r^{2}\right.$ $=0.87$ ) for the fitting with the axial dispersion model also suggest a nearly perfect mixing inside this biocatalyst bed. In fact, as already discussed above, this packed bed has an open pore matrix with a high void volume, which is likely to have a low resistance to mass transfer and fluid motion (Fig. 1).

Using spent grains as cell carrier, a good agreement was found both for the axial dispersion model with a $P e$ number of $5.51 \pm 1.01\left(r^{2}=0.98\right)$ and for a series of three CSTRs. From this, it can be implied that the reactor mixing is not negligible, however it has a lower extent than in the packed bed with Siran. The fibrous structure of the spent grains bed, working like a thick filter media, justifies the lower mixing found for the experiment with this cellulosic carrier.

A recycle was used in both situations but in the case of the spent grains bed its volumetric flow was five times lower than the one used with Siran to avoid fluidization of the lighter spent grains carrier. This fact can also account for the differences in the mixing characteristics.

\subsection{Pectinase production}

During the operation of both packed bed reactors, the free biomass concentration, glucose concentration and pectinase 

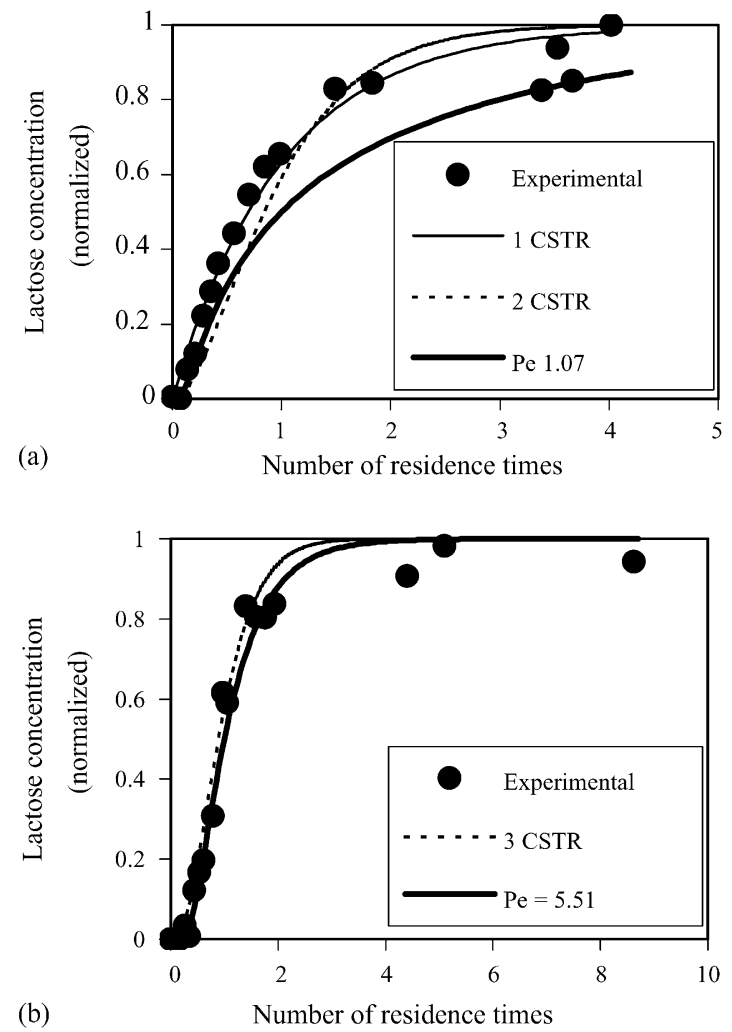

Fig. 3. Tracer response and model fitting for the packed bed with Siran (a) and for the packed bed with spent grains (b).

activity were measured at the reactor's outlet (Fig. 4). Similar values were found for pectinase activities: in the PBR with spent grains the values oscillated between 2.45 and $7.82 \mathrm{U} / \mathrm{ml}$, while in the PBR with Siran the pectinase activities ranged from 3.08 to $7.72 \mathrm{U} / \mathrm{ml}$.

Using the PBR with spent grains, the volumetric productivity $\left(\mathrm{P}_{\mathrm{V}}\right)$ values range from 0.505 to $0.97 \mathrm{U} / \mathrm{ml} \mathrm{h}$ and increase with the dilution rate (Fig. 5). For the Siran packed reactor, productivity also increased with the dilution rate and ranged from 0.39 to $1.68 \mathrm{U} / \mathrm{ml} \mathrm{h}$ (Fig. 5). Comparing all the tested situations, the highest value of $\mathrm{P}_{\mathrm{V}}(1.68 \mathrm{U} / \mathrm{ml} \mathrm{h})$ was found for the Siran bed working with a $D=0.260 \mathrm{~h}^{-1}$ and an inlet sugar concentration of $40 \mathrm{~g} / \mathrm{l}$.

It must be pointed out that, although higher enzyme activities are obtained for higher inlet substrate concentration, this only remains true when total substrate consumption occurs. In fact, increasing $D$ with high glucose concentrations in the inlet is useless, since it results in a higher sugar concentration at the outlet. This was not noticeable for $S_{\text {in }}=$ $20 \mathrm{~g} / \mathrm{l}$ with the tested dilution rates. In the Siran PBR glucose total consumption was achieved only until $D=0.196 \mathrm{~h}^{-1}$ at $S_{\text {in }}=40 \mathrm{~g} / \mathrm{l}$.

As no sample was taken from the packed bed throughout the operation time, the values of the immobilized biomass were estimated using the biomass accumulation trend from Fig. 2. In the case of the Siran bed after the first $240 \mathrm{~h}$ of continuous operation, the average biomass concentration was considered constant and equal to $34 \mathrm{~g} / \mathrm{l}$ of reactor
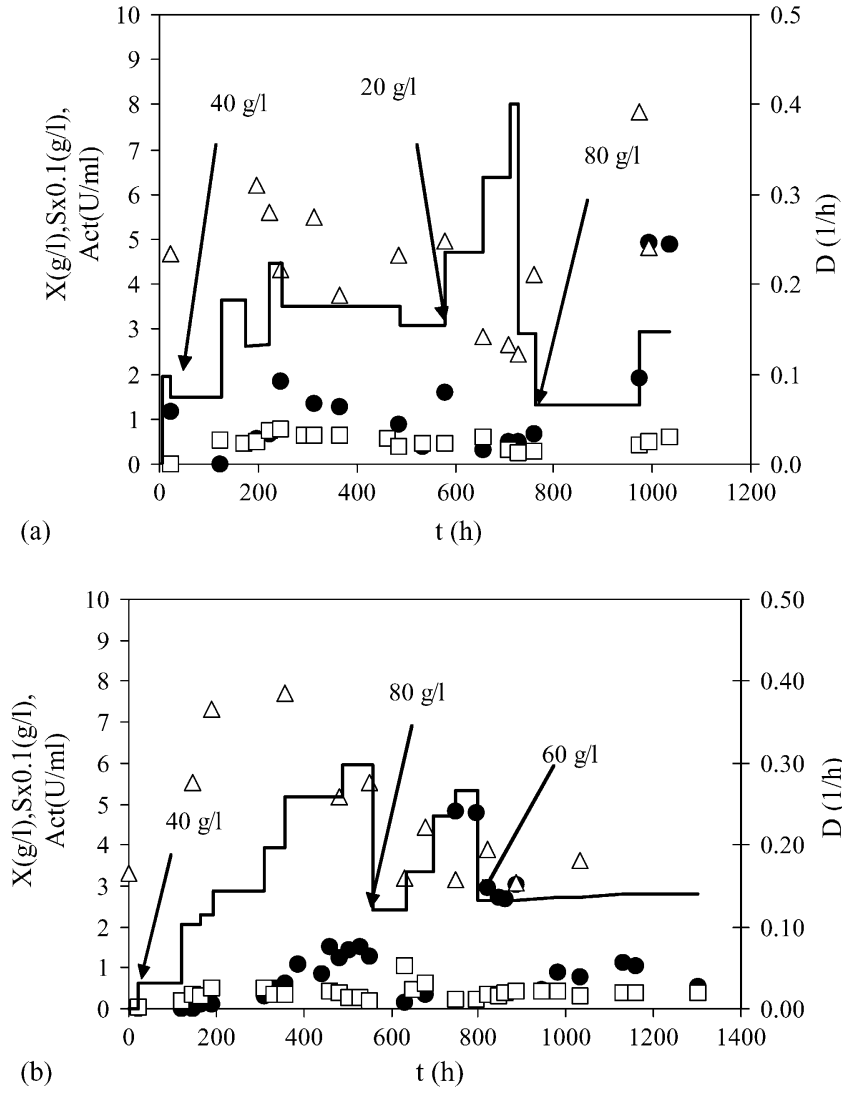

Fig. 4. Evolution of glucose concentration $S$ (circles), free biomass concentration $X$ (squares), pectinase activity Act (triangles), and dilution rate $D$ (一) during PBR operation with spent grains (a) and Siran (b). The arrows mark the changes in the inlet glucose concentration.

volume. A similar behaviour of the bed colonization was assumed for the spent grains, and therefore the biomass concentration was considered also constant $(18.5 \mathrm{~g} / \mathrm{l})$ after $240 \mathrm{~h}$ of the reactor's operation.

Although the packed bed with Siran had a higher biomass concentration, it was unevenly distributed throughout the column. In fact, the bottom of the reactor (about 15-20\% in

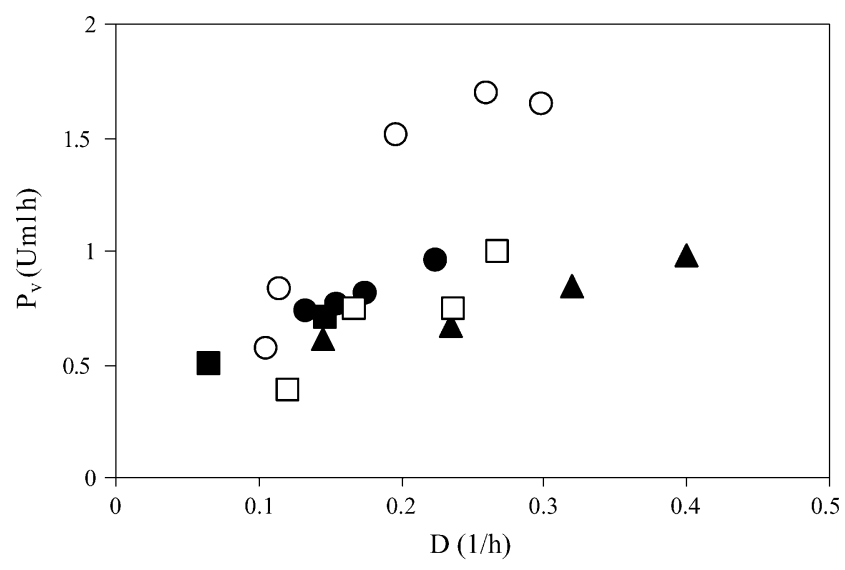

Fig. 5. Pectinase volumetric productivity $\left(\mathrm{P}_{\mathrm{V}}\right)$ for different inlet concentrations of glucose. For PBR with spent grains the data are shown as filled symbols and for PBR with Siran data as empty symbols. Triangles correspond to $S_{\text {in }}=20 \mathrm{~g} / \mathrm{l}$, circles to $S_{\text {in }}=40 \mathrm{~g} / \mathrm{l}$, squares to $S_{\mathrm{i}}=80 \mathrm{~g} / \mathrm{l}$. 
terms of reactor volume) had a large and, in some places, compact yeast accumulation (estimated as $25-30 \%$ of the total biomass in the column) that probably imposed a high mass transfer resistance for glucose and pectinase. The values found for $\mathrm{P}_{\mathrm{V}}$ at $S_{\text {in }}=80 \mathrm{~g} / 1$ are lower than for $S_{\text {in }}=$ $40 \mathrm{~g} / \mathrm{l}$. These contradictory results can also be a consequence of the uneven biomass distribution in the Siran column. As the assays with $S_{\text {in }}=80 \mathrm{~g} / 1$ were performed after the ones with $S_{\text {in }}=40 \mathrm{~g} / \mathrm{l}$, the biomass accumulation at the bottom of the column was increased and these clustered cells are probably less efficient in converting sugar to pectinase due to nutrient restrictions imposed by the high mass transfer resistance.

Both carriers can be successfully used for cell immobilization although, to increase the biomass loads and improve its distribution throughout the column, the surface of the Siran carrier should be activated. In fact, a pretreatment with trimethylchlorosilane favourably changes its surface properties for yeast attachment, as a six-fold decrease is found for the free energy of interaction $\left(\Delta G_{\mathrm{sws}}^{\mathrm{tot}}\right)$ [25].

From the performed assays, it can be concluded that the best results for pectinase production can be achieved using a high $X_{i}$ in the column and a high $D$, together with total glucose consumption.

The better biomass distribution throughout the column obtained in the spent grains PBR and the advantages related to this available by-product from brewing industries make it a suitable option as a cell carrier.

\section{Acknowledgement}

Catarina Almeida and Tomáš Brányik thank F.C.T. for providing the grants $\mathrm{BD} / 18203 / 98$ and SFRH/BPD/3541/ 2000.

\section{References}

[1] Naidu GSN, Panda T. Production of pectolytic enzymes - a review. Bioprocess Eng 1998;19:355-61.

[2] Kashyap DR, Vohra PK, Chopra S, Tewari R. Applications of pectinases in the commercial sector: a review. Bioresour Technol 2001;77:215-27.

[3] Blanco P, Sieiro C, Villa TG. Production of pectic enzymes in yeasts. FEMS Microbiol Lett 1999;175:1-9.

[4] Manachini PL, Parani C, Fortina MG. Pectic enzymes from Aspergillus pullulans LV 10. Enzyme Microb Technol 1988;10(11): $682-5$.

[5] Schwan RF, Cooper RM, Wheals AE. Endopolygalacturonase secretion by Kluyveromyces marxianus and other cocoa pulp-degrading yeasts. Enzyme Microb Technol 1997;21:234-44.

[6] Schwan RF, Rose AH. Polygalacturonase production by Kluyveromyces marxianus: effect of medium composition. J Appl Bacteriol 1994;76:62-7.
[7] Barranco-Florido E, Garcia-Garibay M, Gomez-Ruiz L, Azaola A. Immobilization system of Kluyveromyces marxianus cells in barium alginate for inulin hydrolysis. Process Biochem 2001;37:513-9.

[8] Hartmeier W. Immobilized Biocatalysts - An Introduction. Berlin: Springer-Verlag; 1988.

[9] Ikonomopoulou M, Kanellaki M, Soupioni M, Koutinas AA. Effect of freeze-dried immobilized cells on delignified cellulosic material in low-temperature and ambient-temperature wine making. Appl Biochem Biotechnol 2003;104(1):23-36.

[10] Mensour NA, Margaritis A, Briens CL, Pilkington H, Russel I. Application of immobilized yeasts in the brewing industry. In: Wijffels RH, Buitelaar RM, Bucke C, Tramper J, editors. Immobilised Cells: Basics and Applications. Amsterdam: Elsevier Science; 1996. p. 661-71.

[11] Navrátil M, Gemeiner P, Klein J, Sturdik E, Malovikova A, Nahalka J. Properties of hydrogel materials used for entrapment of microbial cells in production of fermented beverages. Artif Cells Blood Substit Immobil Biotechnol 2002;30(3):199-218.

[12] Pilkington H, Margaritis A, Mensour N, Sobczak J, Hancock I, Russel I. Kappa-carrageenan gel immobilisation of lager brewing yeast. J Inst Brew 1999;105(6):398-404.

[13] Tata M, Bower P, Bromberg S, Duncombe D, Fehring J, Lau VV. Immobilized yeast bioreactor systems for continuous beer fermentation. Biotechnol Prog 1999;15(1):105-13.

[14] Canstein H, Li Y, Timmis KN, Deckwer W-D, Wagner-Dobler I. Removal of mercury from chloralkali electrolysis wastewater by mercury-resistant Pseudomonas putida. Appl Environ Microbiol 1999;65(12):5279-84.

[15] Pérez M, Romero LI, Nebot E, Sales D. Colonisation of porous sintered-glass support in anaerobic thermophilic bioreactors. Bioresour Technol 1997;59:177-83.

[16] Racher AJ, Griffiths JB. Investigation of parameters affecting a fixed bed bioreactor process for recombinant cell lines. Cytotechnology 1993;13(2):125-31.

[17] Srivastava P, Onodera RJ. A comparative evaluation of Cephalosporin C production using various immobilization modes. J Gen Appl Microbiol 1998;44(2):113-7.

[18] Virkajärvi I, Kronlöf J. Long-term stability of immobilized yeast columns in primary fermentation. J Am Soc Brew Chem 1998;56(2):70-5.

[19] Brányik T, Vicente AA, Machado Cruz JM, Teixeira JA. Continuous primary beer fermentation with brewing yeast immobilized on spent grains. J Inst Brew 2002;108(4):410-5.

[20] Brányik T, Vicente AA, Machado Cruz JM, Teixeira JA. Spent grains a new support for brewing yeast immobilisation. Biotechnol Lett 2001;23:1073-8.

[21] Honda S, Nishimura Y, Takahashi M, Chiba H, Kakehi K. A manual method for the spectrophotometric determination of reducing carbohydrates with 2-cyanoacetamide. Anal Biochem 1982;119(1): 194-9.

[22] Miller GL. Use of dinitrosalicylic acid reagent for determination of reducing sugars. Anal Chem 1954;31:426-8.

[23] Henriques M, Gasparetto K, Azevedo J, Oliveira R. Experimental methodology to quantify Candida albicans cell surface hydrophobicity. Biotechnol Lett 2002;24:1111-5.

[24] van Oss CJ, Chaudhury MK, Good RJ. Interfacial Lifshitz-van der Walls and polar interaction in macroscopic systems. Chem Rev 1988;88:927-41.

[25] van Oss CJ. Hydrophobicity of biosurfaces - origin, quantitative determination and interaction energies. Colloid Surf B Biointerfaces 1995;5:91-110.

[26] Nakari-Setälä T, Azeredo J, Henriques M, Oliveira R, Teixeira J, Linder M. Expression of a fungal hydrophobia in Saccharomyces cerevisiae cell wall: effect on cell surface properties and immobilization. Appl Environ Microbiol 2002;68(7):3385-91. 